\title{
Her-2/Neu Overexpression in Invasive Bladder Carcinoma Among a Cohort of Egyptian Patients
}

\author{
Abd El-Aty Shawky ${ }^{\mathrm{a}}$, Amal Abd El hafez ${ }^{\mathrm{a}}$ e, Gehan Mohamed Elosaily \\ Hisham Y. Al-Matubsic ${ }^{\mathrm{c}}$, Adel Farahat ${ }^{\mathrm{d}}$
}

\begin{abstract}
Background: Bladder cancer is one of the commonest malignancies among Egyptian population with high morbidity and mortality rates. Human epidermal growth factor receptor-2 (Her-2/Neu) seems to play role in the pathogenesis and prognosis of bladder carcinomas; however, its expression and prognostic significance were variable between different studies. This study evaluates the status of Her-2/Neu protein expression in invasive carcinomas of the bladder among a cohort of Egyptian patients using immunohistochemistry (IHC) and determines its relation to some clinicopathological factors.
\end{abstract}

Methods: A number of 32 invasive bladder carcinoma patients treated with radical cystectomy were enrolled. Tumor sections were immunostained using anti-Her-2/Neu antibody and were evaluated by at least two pathologists. Statistical analysis was carried out with the Statistical Software Package Standard (SPSS).

Results: Her-2/Neu membranous staining was observed in 20 carcinomas $(62.5 \%)$. Statistical analysis revealed significant direct association between Her-2/Neu and both increasing grade of carcinoma $(P=0.001)$ and depth of tumor invasion $(P \leq 0.001)$. Patient's gender, histological subtype and the presence of bilharzial cystitis did not have any significant association with Her-2/Neu overexpression.

Conclusion: Her-2/Neu immunopositivity was observed in a considerable proportion of cases with association to adverse prognostic

Manuscript accepted for publication November 15, 2013

${ }^{\mathrm{a}}$ Department of Pathology, Faculty of Medicine, Mansoura University, Egypt

${ }^{b}$ Department of Pathology, Faculty of Medicine, Assiut University, Egypt

${ }^{c}$ Physiology Department, Al Maarefa College for Science and

Technology, Riyadh, KSA; The Royal University for Medical Sciences, Amman, Jordan

${ }^{\mathrm{d}}$ Department of Urology, Faculty of Medicine, Suez Canal University, Ismailia, Egypt

${ }^{\mathrm{e}}$ Corresponding author: Amal Abd El hafez, Pathology Department,

Faculty of Medicine, Mansoura University, Egypt.

Email: amalabdelhafez@gmail.com

doi: http://dx.doi.org/10.4021/wjnu123w factors, thus patients with high-grade, deeply invasive carcinoma of the bladder may benefit from Her-2/Neu-targeted therapies after radical cystectomy.

Keywords: Her-2/Neu; Immunohistochemistry; Overexpression; Bladder carcinoma; Clinicopathological factors

\section{Introduction}

Bladder cancer is the seventh most common malignancy worldwide, and the eighth leading cause of cancer death in men [1]. Among Egypt National Cancer Institute series (2002 - 2003), the urinary bladder cancer was the second common malignancy $(10.4 \%)$, being the most frequent cancer among males $(16.2 \%)$ and fifth common among females (4.4\%) [2], which is strikingly higher than most other parts of the world. Despite the progress of therapeutic means, up to $30 \%$ of patients who suffer from noninvasive tumors in the muscularis propria and $50 \%$ of those with invasive tumors in the detrusor muscle present with recurrences or they die $[3,4]$. Given the dismal prognosis of advanced bladder carcinoma, more effective systemic therapy is needed [5].

Bladder cancer has several molecular alterations and complex biological pathways that regulate cellular processes, such as proliferation, differentiation, angiogenesis, metastasis and apoptosis. The discovery of new biological markers, may lead to the improvement of clinical prediction and the personalization of therapeutic approaches of bladder cancer patients with the purpose of reducing the risk of progression. Lately, many studies have concentrated on the evaluation of certain markers involved in the regulation of the cell cycle, among them being the human epidermal growth factor receptors, which can represent promising therapeutic targets $[5,6]$.

The human epidermal growth factor receptor-2 (Her-2/ Neu, also known as erbB2 and Her-2), encoded by c-erbB2 gene localized to chromosome $17 \mathrm{q}$, is a $185 \mathrm{kDa}$ membranespanning glycoprotein with tyrosine kinase activity. Ligand binding of these receptors causes its dimerizations and activates the intracellular kinase domain, leading to phosphory- 
Table 1. Clinicopathological Variables of Invasive Bladder Carcinomas and Their Associations With Her-2/ Neu Overexpression

\begin{tabular}{|c|c|c|c|c|}
\hline \multirow{2}{*}{ Variable } & & \multicolumn{2}{|c|}{ Her-2/Neu expression } & \multirow{2}{*}{ P value } \\
\hline & & Negative & Positive & \\
\hline \multicolumn{5}{|l|}{ Gender } \\
\hline Male & $20(62.5 \%)$ & $9(45 \%)$ & $11(55 \%)$ & 0.272 \\
\hline Female & $12(37.5 \%)$ & $3(25 \%)$ & $9(75 \%)$ & \\
\hline \multicolumn{5}{|l|}{ Histology } \\
\hline $\mathrm{SCC}$ & $14(43.8 \%)$ & $5(35.7 \%)$ & $9(64.3 \%)$ & \\
\hline TCC & $13(40.6 \%)$ & $6(47 \%)$ & $7(53 \%)$ & 0.317 \\
\hline $\mathrm{AC}$ & $5(15.6 \%)$ & $1(20 \%)$ & $4(80 \%)$ & \\
\hline \multicolumn{5}{|l|}{ Grade } \\
\hline G1 & $2(6.3 \%)$ & $2(100 \%)$ & $0(0 \%)$ & \multirow{3}{*}{$0.001 *$} \\
\hline G2 & $17(53.1 \%)$ & $9(53 \%)$ & $8(47 \%)$ & \\
\hline G3 & $13(40.6 \%)$ & $1(7.7 \%)$ & $12(92.3 \%)$ & \\
\hline \multicolumn{5}{|c|}{ Depth of invasion } \\
\hline $\mathrm{pT} 2$ & $10(31.3 \%)$ & $8(80 \%)$ & $2(20 \%)$ & \multirow{2}{*}{$<0.001 *$} \\
\hline pT3 & $22(68.7 \%)$ & $4(18.2 \%)$ & $18(81.8 \%)$ & \\
\hline \multicolumn{5}{|c|}{ Bilharzial cystitis } \\
\hline Present & $13(40.6 \%)$ & $5(38.5 \%)$ & $8(61.5 \%)$ & 0.929 \\
\hline Absent & $19(59.4 \%)$ & $7(36.8 \%)$ & $12(63.2 \%)$ & \\
\hline Total & $32(100 \%)$ & $12(37.5 \%)$ & $20(62.5 \%)$ & \\
\hline
\end{tabular}

SCC: squamous cell carcinoma; TCC: transitional cell carcinoma; AC: adenocarcinoma. ${ }^{*} \mathrm{P}$ value is significant if $\leq 0.05$.

lation of tyrosine residues and the transduction of mitogenic signals. Thus, Her-2/Neu plays a fundamental role in cell growth, differentiation survival, and migration [7], and abnormal activation of Her-2/Neu leads to oncogenic transformation of the cell [8].

Her-2/Neu gene amplification and/or the protein overexpression have been long time considered as bad prognostic factors in several carcinomas, particularly in breast and ovarian carcinomas $[9,10]$. Recently, anti-Her-2/Neu antibody, also known as transtuzumab or Herceptin, has shown its efficiency in these tumors' therapy, both alone and in combination with Cisplatin. Consequently, assessment of Her-2/Neu status has assumed therapeutic significance [11].

Her-2/Neu appears to play role in the pathogenesis of bladder carcinoma, however, its expression was variable between different studies, ranging between 9 and 81\% [12-16]. Furthermore, analysis of Her-2/Neu overexpression has been the subject of numerous studies in an attempt to make correlations with clinicalpathological parameters of prognosis, with discrepant results [3, 17-19]. It has been identified as an independent predictor for disease-related survival in muscleinvasive bladder carcinomas [18].

Aside from its prognostic significance, accurate determination of Her-2/Neu status in patients with bladder cancer 


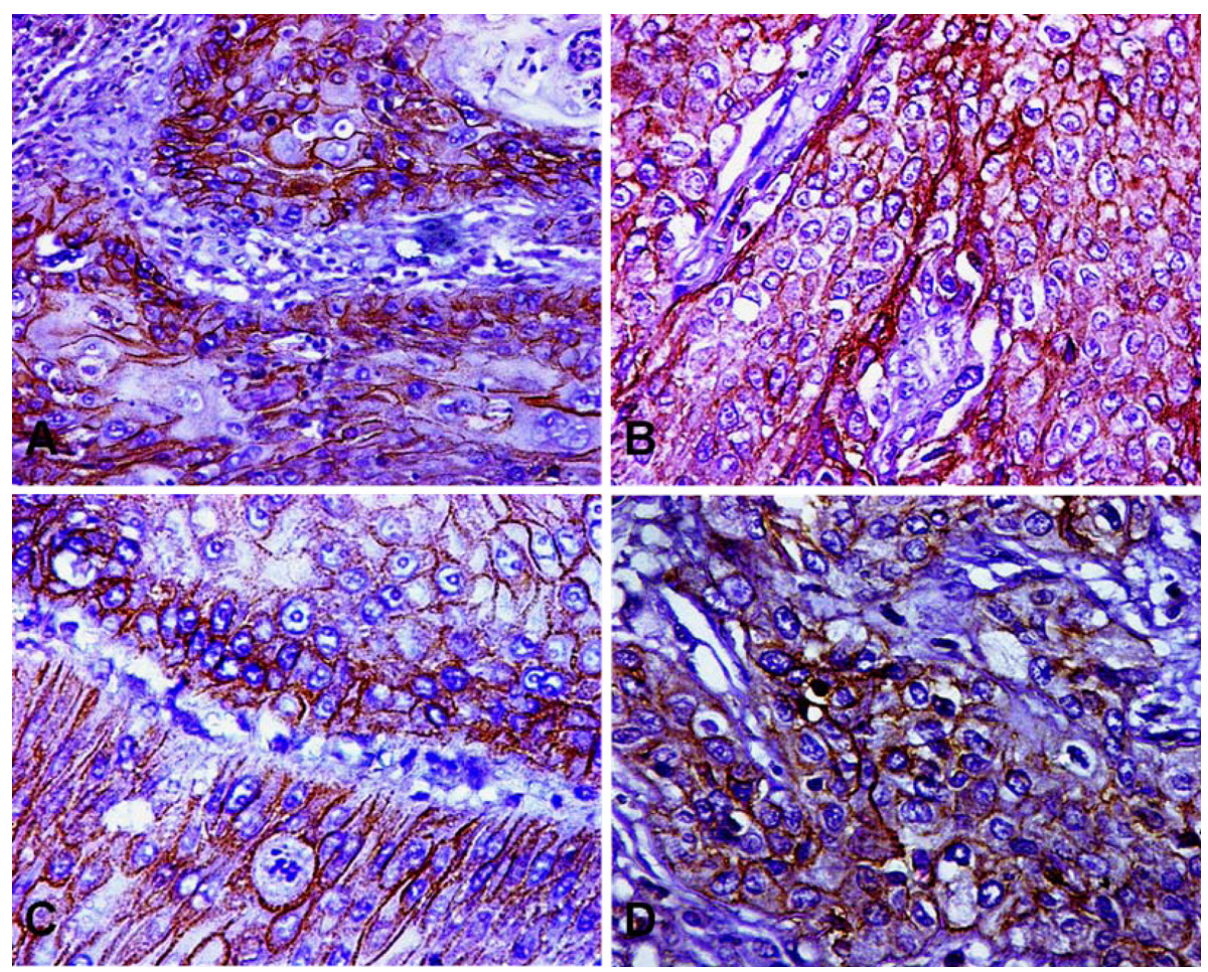

Figure 1. Her-2/Neu circumferential membrane staining in more than $10 \%$ of the tumor cells in different cases of bladder carcinoma, (A) squamous cell carcinoma (DAB, $\times 100$ ); (B) transitional cell carcinoma with bilharzial cystitis; (C) low grade and $(D)$ high grade transitional cell carcinomas $(D A B, \times 200)$.

has therapeutic implications [11]. So, this study is performed to evaluate the status of Her-2/Neu protein expression in invasive bladder carcinomas of the bladder among a cohort of Egyptian patients using immunohistochemistry (IHC). In addition, the study determines its relation to some clinicopathological factors.

\section{Materials and Methods}

\section{Patient selection and clinicopathological evaluation}

A number of 32 Egyptian patients of invasive urinary bladder carcinoma treated with radical cystectomy were enrolled in this study. Only invasive bladder tumors were included based on availability of representative paraffin embedded tumor tissues obtained after cystectomies, fixed in $10 \%$ formalin, processed through routine histopathological technique. Patient gender was obtained from medical records. Hematoxylin and eosin stained slides prepared from all the specimens were reviewed for histological subtyping, grading according to World Health Organization/International Society of Urological Pathologists criteria, evaluating the depth of tumor invasion, and detection of associated bilharzial cystitis. One representative section containing invasive tumor was selected for immunohistochemical analysis.

\section{Immunohistochemistry (IHC)}

After deparaffinization and rehydration, 4 - $5 \mu \mathrm{m}$ thick sections on coated slides were heat-pretreated in citrate buffer $\left(\mathrm{pH} 6.0\right.$ at $92{ }^{\circ} \mathrm{C}$ ) and immunostained using anti-Her-2/Neu antibody (CB11, Novocastra at dilution 1:50). The avidin-biotin technique was performed using diaminobenzidin (DAB) for visualization and hematoxylin for counterstaining. Appropriate negative controls for the immunostaining, consisting of histological sections of each case processed without the addition of primary antibody were prepared along with a positive control sections prepared from breast carcinoma with known positivity for Her-2/Neu with each IHC run.

\section{Scoring of Her-2/Neu overexpression}

Immunostained sections were evaluated under light microscope independently by at least two pathologists. The membranous staining intensity and pattern were considered for scoring according the following scheme: 0 , no staining or membrane staining observed in less than $10 \%$ of the tumor cells; $1+$, partial faint membrane staining in more than $10 \%$ of the tumor cells; $2+$, circumferential weak to moderate staining observed in more than $10 \%$ of the tumor cells; $3+$, circumferential strong membrane staining observed in more than $10 \%$ of the tumor cells. Areas that were poorly 
Her-2 Expression in Relation to Grade of Bladder Carcinoma.

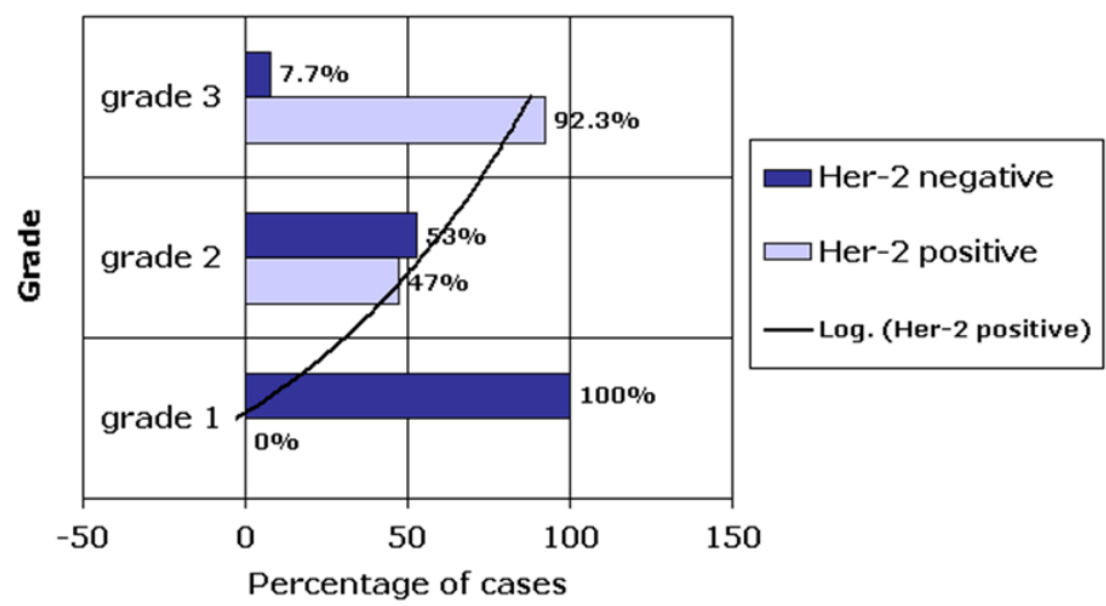

Figure 2. Her-2/Neu overexpression has a significant direct association with increasing grade of bladder carcinoma.

preserved, crushed, folded, or retracted were specifically avoided. Scores of $2+$ and $3+$ were considered positive for Her-2/Neu [11, 20].

\section{Statistical analysis}

Statistical analysis was carried out with the Statistical Software Package Standard (SPSS) version 16.0. The association of Her-2/Neu protein expression with the other invasive bladder carcinoma variables was assessed by the Pearson's Chi-square test. Statistical significance was reached if a $\mathrm{P} \leq$ 0.05 was obtained.

\section{Results}

\section{Clinicopathological features}

Twenty male patients and 12 female patients with pathologically confirmed invasive urinary bladder carcinoma diagnosed from radical cystectomy specimens were included in this study. On histopathologic examination, squamous cell carcinoma was the most frequent subtype (43.8\%) followed by transitional cell carcinoma (40.6\%), whilst adenocarcinoma was the least common subtype. More than half of carcinomas were grade $2(53.1 \%)$, and about $59 \%$ of them were not associated with bilharzial cystitis. Approximately, 31\% of carcinomas invaded the muscle layer and the remaining $(68.7 \%)$ invaded down to the perivesical tissue (Table 1).

\section{Her-2/Neu overexpression and its association with the tested variables}

Among the 32 investigated bladder carcinomas, Her-2/Neu membranous staining was observed in 20 tumors $(62.5 \%)$ (Fig. 1). Her-2/Neu was more frequently overexpressed in female patients $(75 \%)$, adenocarcinomas and squamous cell carcinomas $(80 \%$ and $64.3 \%$ respectively), grade 3 carcinomas $(92.3 \%)$ and carcinomas invading the perivesical fat (pT3) (81.8\%). However, Her-2/Neu immunopositivity was nearly equal in both bilharzial-associated carcinoma and non-associated carcinomas. A significant direct association was observed between Her-2/Neu protein overexpression and both increasing grade of carcinoma $(\mathrm{P}=0.001)$ (Fig. 2), and depth of tumor invasion $(\mathrm{P} \leq 0.001)$. In contrast, other tested variables including patient's gender, tumor histological subtype and the presence or absence of bilharzial cystitis did not have any significant association with Her-2/Neu expression profile $(\mathrm{P}=0.272,0.317,0.929$ respectively) (Table $1)$.

\section{Discussion}

Lately immunohistochemical studies on urinary bladder carcinomas are focused on the evaluation of several markers involved in the cell cycle control, with the aim of assessing the predictive factors of the disease [21]. The prognostic value of Her-2/Neu in bladder carcinoma has not yet been established; however, the success of trastuzumab therapy in patients with breast carcinoma has stimulated interest in exploring the potentiality of using this therapy for patients with bladder carcinoma [7, 22].

There are wide variations in the reports of different investigators regarding the frequency of Her-2/Neu expression in urinary bladder carcinoma, however, several studies that employed immunohistochemistry to detect Her-2/Neu overexpression in urothelial carcinomas, have yielded a tremen- 
dous range of positive expression rates in contrast to studies based on gene amplification [19, 22]. A possible explanation is that, Her-2/Neu protein overexpression is believed to arise from a combination of two mechanisms. The first is gene amplification which is not a common mechanism in bladder cancer [3]. The second mechanism is upregulated transcription which reflects the nature of the Her-2/Neu protein as a growth factor. Therefore, higher levels of transcription factor, even in the absence of gene amplification result in increased Her-2/Neu protein expression [23, 24]. In the present series, Her-2/Neu expression was assessed by immunohistochemistry (IHC), which is the method most commonly used for breast cancer. There was a positive Her-2/Neu status in $62.5 \%$ of bladder carcinomas. This rate was within the range of previously published data $[15,17,19,22]$, confirming the efficiency of IHC in the assessment of Her-2/Neu in bladder carcinoma.

In breast, ovarian, prostate, pancreatic and liver malignant tumors, Her-2/Neu overexpression is associated with bad prognosis [25]. Nonetheless, the prognostic significance of Her-2/Neu expression in urinary bladder carcinoma is highly controversial, with several conflicting results in the published literature. Thus, although a series of studies [3,11, $15,21,26]$, have reported a negative prognostic value and a more aggressive clinical behavior of Her-2/Neu expression in bladder carcinoma [21,26], others [11, 25], have found no prognostic association, and some others [27, 28], have linked it to a better clinical outcome. In the current series, Her-2/ Neu overexpression was significantly associated with tumor differentiation grade as well as the depth of tumor invasion with the overexpression more prevalent in the high grade and deeply invasive specimens reflecting the aggressiveness of the tumor cells. This is consistent with the findings of several recent reports $[7,20,21,25,26,29]$, in which Her-2/ $\mathrm{Neu}$ overexpression was represented as a prognostic factor for adverse disease outcome [26].

In agreement with El Gehani et al [22], Her-2/Neu did not show any association with patient gender in the present cohort. In the later study [22], which included 39 bladder carcinomas of different histological subtypes, Her-2/Neu expression was higher in transitional cell carcinoma (TCC) and adenocarcinomas (AC) as compared to squamous cell carcinoma (SCC) with a significant statistical difference. These findings were contradictory to the data obtained from the current work, as well as from a study by Eissa et al [30], since higher Her-2/Neu expression rates were observed in AC and SCC compared to TCC with no significant difference between groups. These discordant results may be attributed to the small number of AC and SCC samples tested in the former study [22]. Additionally, the presence or absence of bilharzial cystitis seemed to have no effect on Her-2/Neu expression profile among the present cohort. Similarly, Eissa et al [30], confirmed that no significant difference does exist between the bilharzial and nonbilharzial cancer groups.
In conclusion, differences in both the incidence of Her2/Neu expression and its prognostic significance in bladder carcinoma could be explained by different methodologies (gene amplification versus protein overexpression), or different techniques used (PCR, fluorescence in situ hybridization, and immunohistochemistry), and different antibodies applied for IHC, in addition to the inconsistent criteria set for detecting IHC positivity. Thus, the literature in this field is extremely difficult to compare, and significant conclusions are hard to draw from the aggregate data $[7,11,22]$. Nevertheless, our results suggest that the Her-2/Neu expression could offer supplementary information for prognosis in patients with invasive bladder carcinoma, being observed in a considerable proportion of cases with association to adverse prognostic factors. Comprehensive researches with larger sample sizes are needed for further elucidation of the role of this oncogene in bladder carcinoma. Moreover, patients with bladder cancers should be tested for Her-2/Neu status for selection of proper candidates who may benefit from adjuvant Her-2/Neu-targeted therapies after radical cystectomy.

\section{Disclosure}

No relevant financial affiliations or conflicts of interest to disclose.

\section{References}

1. Edwards BK, Ward E, Kohler BA, Eheman C, Zauber AG, Anderson RN, Jemal A, et al. Annual report to the nation on the status of cancer, 1975-2006, featuring colorectal cancer trends and impact of interventions (risk factors, screening, and treatment) to reduce future rates. Cancer. 2010;116(3):544-573.

2. Elattar IA, Ali-eldin NH, Moneer MM, Elbasmy AA, Belal D, Aref N, Kamel M, et al. Cancer registry 20022003, National Cancer Institute Cairo university, Egypt. Part II, section 1. 2003; pp. 15, 50 of 75.

3. Kruger S, Weitsch G, Buttner H, Matthiensen A, Bohmer T, Marquardt T, Sayk F, et al. HER2 overexpression in muscle-invasive urothelial carcinoma of the bladder: prognostic implications. Int J Cancer. 2002;102(5):514518.

4. Matsushita K, Cha EK, Matsumoto K, Baba S, Chromecki TF, Fajkovic H, Sun M, et al. Immunohistochemical biomarkers for bladder cancer prognosis. Int J Urol. 2011;18(9):616-629.

5. Grivas PD, Day M, Hussain M. Urothelial carcinomas: a focus on human epidermal receptors signaling. Am J Transl Res. 2011;3(4):362-373.

6. Marin AP, Arranz EE, Sanchez AR, Aunon PZ, Baron MG. Role of anti-Her-2 therapy in bladder carcinoma. J 
Cancer Res Clin Oncol. 2010;136(12):1915-1920.

7. Atis G, Arisan S, Dalkilinc A. Determination of Her2/Neu gene amplification and protein overexpression in bladder transitional cell carcinoma. Adv Mol Biol. 2007;1:89-94.

8. Olayioye MA, Neve RM, Lane HA, Hynes NE. The ErbB signaling network: receptor heterodimerization in development and cancer. EMBO J. 2000;19(13):31593167.

9. Slamon DJ, Godolphin W, Jones LA, Holt JA, Wong SG, Keith DE, Levin WJ, et al. Studies of the HER-2/ neu proto-oncogene in human breast and ovarian cancer. Science. 1989;244(4905):707-712.

10. Pegram MD, Slamon DJ. Combination therapy with trastuzumab (Herceptin) and cisplatin for chemoresistant metastatic breast cancer: evidence for receptorenhanced chemosensitivity. Semin Oncol. 1999;26(4 Suppl 12):89-95.

11. Jimenez RE, Hussain M, Bianco FJ, Jr., Vaishampayan U, Tabazcka P, Sakr WA, Pontes JE, et al. Her-2/neu overexpression in muscle-invasive urothelial carcinoma of the bladder: prognostic significance and comparative analysis in primary and metastatic tumors. Clin Cancer Res. 2001;7(8):2440-2447.

12. Sato K, Moriyama M, Mori S, Saito M, Watanuki T, Terada K, Okuhara E, et al. An immunohistologic evaluation of C-erbB-2 gene product in patients with urinary bladder carcinoma. Cancer. 1992;70(10):2493-2498.

13. Mellon JK, Lunec J, Wright C, Horne CH, Kelly P, Neal DE. C-erbB-2 in bladder cancer: molecular biology, correlation with epidermal growth factor receptors and prognostic value. J Urol. 1996;155(1):321-326.

14. Chow NH, Chan SH, Tzai TS, Ho CL, Liu HS. Expression profiles of ErbB family receptors and prognosis in primary transitional cell carcinoma of the urinary bladder. Clin Cancer Res. 2001;7(7):1957-1962.

15. Gandour-Edwards R, Lara PN, Jr., Folkins AK, LaSalle JM, Beckett L, Li Y, Meyers FJ, et al. Does HER2/ neu expression provide prognostic information in patients with advanced urothelial carcinoma? Cancer. 2002;95(5):1009-1015.

16. Wester K, Sjostrom A, de la Torre M, Carlsson J, Malmstrom PU. HER-2--a possible target for therapy of metastatic urinary bladder carcinoma. Acta Oncol. 2002;41(3):282-288.

17. Caner V, Turk NS, Duzcan F, Tufan NL, Kelten EC, Zencir S, Dodurga $Y$, et al. No strong association between HER-2/neu protein overexpression and gene amplification in high-grade invasive urothelial carcinomas. Pathol Oncol Res. 2008;14(3):261-266.

18. Hansel DE, Swain E, Dreicer R, Tubbs RR. HER2 overexpression and amplification in urothelial carcinoma of the bladder is associated with MYC coamplification in a subset of cases. Am J Clin Pathol. 2008;130(2):274-281.

19. Naik DS, Sharma S, Ray A, Hedau S. Epidermal growth factor receptor expression in urinary bladder cancer. Indian J Urol. 2011;27(2):208-214.

20. Jalali Nadoushan MR, Taheri T, Jouian N, Zaeri F. Overexpression of HER-2/neu oncogene and transitional cell carcinoma of bladder. Urol J. 2007;4(3):151-154.

21. Enache M, Simionescu CE, Stepan A. EGFR and Her2/ neu immunoexpression in papillary urothelial bladder carcinomas. Rom J Morphol Embryol. 2013;54(1):137141.

22. El Gehani K, Al-Kikhia L, Emaetig F, Syrjanen K, AlFituri O, Elzagheid A. Over-expression of HER-2 is associated with the stage in carcinomas of the urinary bladder. Libyan J Med. 2012;7.

23. Latif Z, Watters AD, Dunn I, Grigor K, Underwood MA, Bartlett JM. HER2/neu gene amplification and protein overexpression in G3 pT2 transitional cell carcinoma of the bladder: a role for anti-HER2 therapy? Eur J Cancer. 2004;40(1):56-63.

24. Ohta JI, Miyoshi Y, Uemura H, Fujinami K, Mikata K, Hosaka M, Tokita Y, et al. Fluorescence in situ hybridization evaluation of c-erbB-2 gene amplification and chromosomal anomalies in bladder cancer. Clin Cancer Res. 2001;7(8):2463-2467.

25. Alexa A, Baderca F, Zahoi DE, Lighezan R, Izvernariu D, Raica M. Clinical significance of Her2/neu overexpression in urothelial carcinomas. Rom J Morphol Embryol. 2010;51(2):277-282.

26. Skagias L, Politi E, Karameris A, Sambaziotis D, Archondakis A, Vasou O, Ntinis A, et al. Prognostic impact of HER2/neu protein in urothelial bladder cancer. Survival analysis of 80 cases and an overview of almost 20 years' research. J BUON. 2009;14(3):457-462.

27. Korkolopoulou P, Christodoulou P, Kapralos P, Exarchakos M, Bisbiroula A, Hadjiyannakis M, Georgountzos $\mathrm{C}$, et al. The role of p53, MDM2 and c-erb B-2 oncoproteins, epidermal growth factor receptor and proliferation markers in the prognosis of urinary bladder cancer. Pathol Res Pract. 1997;193(11-12):767-775.

28. Vollmer RT, Humphrey PA, Swanson PE, Wick MR, Hudson ML. Invasion of the bladder by transitional cell carcinoma: its relation to histologic grade and expression of p53, MIB-1, c-erb B-2, epidermal growth factor receptor, and bcl-2. Cancer. 1998;82(4):715-723.

29. Kolla SB, Seth A, Singh MK, Gupta NP, Hemal AK, Dogra PN, Kumar R. Prognostic significance of Her2/ neu overexpression in patients with muscle invasive urinary bladder cancer treated with radical cystectomy. Int Urol Nephrol. 2008;40(2):321-327.

30. Eissa S, Ali HS, Al Tonsi AH, Zaglol A, El Ahmady O. HER2/neu expression in bladder cancer: relationship to cell cycle kinetics. Clin Biochem. 2005;38(2):142-148. 